Article (refereed) - postprint

Kay, A.L.; Rudd, A.C.; Davies, H.N.; Kendon, E.J.; Jones, R.G. 2015. Use of very high resolution climate model data for hydrological modelling: baseline performance and future flood changes. Climatic Change, 133 (2). 193-208. 10.1007/s10584-015-1455-6

(C) Springer Science+Business Media Dordrecht 2015

This version available http://nora.nerc.ac.uk/510130/

NERC has developed NORA to enable users to access research outputs wholly or partially funded by NERC. Copyright and other rights for material on this site are retained by the rights owners. Users should read the terms and conditions of use of this material at http://nora.nerc.ac.uk/policies.html\#access

This document is the author's final manuscript version of the journal article, incorporating any revisions agreed during the peer review process. There may be differences between this and the publisher's version. You are advised to consult the publisher's version if you wish to cite from this article.

The final publication is available at Springer via http://dx.doi.org/10.1007/s10584-015-1455-6

Contact CEH NORA team at noraceh@ceh.ac.uk

The NERC and CEH trademarks and logos ('the Trademarks') are registered trademarks of NERC in the UK and other countries, and may not be used without the prior written consent of the Trademark owner. 


\title{
Use of very high resolution climate model data for hydrological modelling: baseline performance and future flood changes
}

Kay, A.L. ${ }^{1}$, Rudd A.C. ${ }^{1}$, Davies, H.N. ${ }^{1}$, Kendon, E.J. ${ }^{2}$ and Jones R.G. ${ }^{2}$

${ }^{1}$ Centre for Ecology \& Hydrology, Wallingford, UK

${ }^{2}$ Met Office Hadley Centre, Exeter, UK

Accepted by Climatic Change, June 2015 (doi:10.1007/s10584-015-1455-6)

\begin{abstract}
Increasingly, data from Regional Climate Models (RCMs) are used to drive hydrological models, to investigate the potential water-related impacts of climate change, particularly for flood and droughts. Generally, some form of further downscaling of RCM data has been required, but recently the first decadallength runs of very high resolution RCMs (with convection-permitting scales) have been performed. Here, a set of such runs for southern Britain has been used to drive a gridded hydrological model. Results using a $1.5 \mathrm{~km} \mathrm{RCM} \mathrm{nested}$ in a $12 \mathrm{~km}$ RCM driven by European-reanalysis boundary conditions show that the $1.5 \mathrm{~km}$ RCM generally performs worse than the $12 \mathrm{~km}$ RCM for simulating river flows in 32 example catchments. The clear spatial patterns of bias are consistent with bias patterns shown in the RCM precipitation data. Results using $1.5 \mathrm{~km}$ and $12 \mathrm{~km} \mathrm{RCM}$ runs for the current climate and a potential future climate (driven by GCM boundary conditions) show clear differences in projected changes in flood peaks. The $1.5 \mathrm{~km}$ RCM tends towards larger increases than the $12 \mathrm{~km} \mathrm{RCM}$, particularly in spring and winter. If robust, this could have important consequences for adaptation planning under climate change, but further research is required, particularly given the greater biases in the baseline flow simulations driven by $1.5 \mathrm{~km} \mathrm{RCM}$ data, and the use of only a single short future climate projection.
\end{abstract}

\section{Keywords}

Climate change; hydrological impacts; rainfall-runoff; regional climate model; flow duration; flood frequency

\section{Introduction}

Regional climate models (RCMs) are increasingly relied upon to assess the potential impacts of climate change for sectors and regions across the globe (Hewitson et al. 2014). Such models have finer resolutions than the global climate models (GCMs) in which they are nested, and so provide better representations of, for example, topography and atmospheric movements and the effects these have on rainfall patterns and intensities. Such improvements over GCMs are particularly important if the data are being used to drive 
hydrological models, to assess the potential impacts of climate change on river flows, and are even more important if the focus is hydrological extremes.

Previous studies driving hydrological models directly with data from RCMs over Europe have used data on grids with resolutions of $\sim 12-50 \mathrm{~km}$ (e.g. Graham et al. 2007, Dankers and Feyen 2008, Bell et al. 2012, Kay and Jones 2012a,b). This generally required some form of further downscaling, particularly for precipitation data, before use for hydrological modelling, with the downscaling sometimes being combined with bias-correction. For example, Prudhomme et al. (2012) used quantile-mapping to downscale and bias-correct $25 \mathrm{~km} \mathrm{RCM}$ precipitation to $1 \mathrm{~km}$. However, such adjustments have to be applied with care. Several recent papers have questioned the supposed improvements for hydrological modelling brought by bias-correction (Addor and Seibert 2014, Huang et al. 2014, Ehret et al. 2012). Also, biases in different variables can compensate for each other when combined (e.g. Fischer and Knutti 2013), so separate bias correction of different variables could introduce inconsistencies; this could be important for the potential evaporation estimates required by hydrological models (Kay et al. 2013).

Recently, developments in technology and computing power have enabled further improvements in spatial resolution of climate models, including a further level of nesting of models. Specifically, a recent project (CONVEX) has involved nesting a $1.5 \mathrm{~km} \mathrm{RCM}$ in a $12 \mathrm{~km} \mathrm{RCM}$, which is in turn either driven by European-reanalysis (ERA-Interim) boundary conditions (Kendon et al. 2012) or nested in the HadGEM3 GCM (Kendon et al. 2014). The ERA-driven runs cover the period 1989-2008, while two pairs of GCM-driven runs are available, one approximating the current climate (1996-2009) and the second a potential future climate of the end of the $21^{\text {st }}$ century assuming RCP8.5 anthropogenic forcings (Riahi et al. 2011). The $12 \mathrm{~km} \mathrm{RCM} \mathrm{covers} \mathrm{Europe,} \mathrm{while} \mathrm{the} 1.5 \mathrm{~km} \mathrm{RCM}$ only covers southern Britain. The $1.5 \mathrm{~km}$ resolution is sufficiently fine so as to be 'convection-permitting'; such models do not require schemes parameterising convective storms, whereas lower resolution models rely on such schemes, which can be a significant source of uncertainty in modelled precipitation, especially in summer (Kendon et al. 2012).

Analyses of rainfall from the CONVEX ERA-driven runs show that the $1.5 \mathrm{~km}$ $\mathrm{RCM}$ generates sub-daily rainfall that is more realistic in terms of duration and spatial extent than that generated by the $12 \mathrm{~km} \mathrm{RCM}$, although heavy rain can be too intense (Kendon et al. 2012). However, analyses of daily rainfall did not show clear evidence of improvements with increasing resolution (Chan et al. 2013). Similar results were found for a $2.2 \mathrm{~km}$ convection-permitting RCM covering the Alps, nested in a 12km ERA-driven RCM (Ban et al. 2014). Analyses of hourly rainfall projections from the CONVEX GCM-driven runs show increases in the intensity of heavy summer precipitation in the $1.5 \mathrm{~km}$ $\mathrm{RCM}$ that are not seen in the $12 \mathrm{~km} \mathrm{RCM}$, with increases in heavy winter precipitation similar in the $1.5 \mathrm{~km}$ and $12 \mathrm{~km}$ RCMs (Kendon et al. 2014). The $1.5 \mathrm{~km}$ RCM shows uniform increases in intensity across a range of return periods, while the $12 \mathrm{~km}$ RCM shows decreases at shorter return periods and 
increases at longer return periods (Chan et al. 2014). There is little confidence in the $12 \mathrm{~km} \mathrm{RCM}$ projections at long return periods though, as they are linked to unphysical grid-point storms.

Catchments have different characteristic time-scales of response to precipitation inputs, with key influencing factors being catchment size, slope, urbanisation and soil/bedrock permeability (Kjeldsen 2007). This means that, although sub-daily rainfall distribution is important for flood-generation in very small or responsive catchments, rainfall accumulations at daily and longer durations, and antecedent soil moisture, are generally more important in moderately sized or large catchments (e.g. Smith et al. 2014, Addor and Seibert 2014), particularly those with a significant component of their flow derived from groundwater sources (Chiverton et al. 2015). Thus the benefits of very high resolution RCM data for hydrological modelling may depend on the characteristics of the catchment being modelled. Similarly, the implications of differing future rainfall projections between RCM resolutions could vary by catchment. However, winter is the main fluvial flood season in Britain, especially southern Britain (Bayliss and Jones 1993), so summer rainfall differences are likely to be less important.

Using the CONVEX data, the aims of this paper are to

- Use data from the Baseline ERA-driven runs to test the performance of very high resolution climate model data for hydrological modelling of river flows.

- Use data from the Current and Future GCM-driven runs to investigate the effect of RCM resolution on projections of change in peak river flows.

Using a national gridded hydrological model, the first analysis looks at performance in 32 gauged catchments across southern Britain, compared to both gauged flows and use of observed input data to drive the hydrological model. The second analysis uses the same national gridded hydrological model and presents spatial maps of flood changes, both annually and seasonally.

\section{Methods and data}

\subsection{Hydrological model}

A national gridded hydrological model is applied; CLASSIC-GB (Crooks et al. 2014). This model was recently developed from a semi-distributed catchmentbased model CLASSIC (Climate and LAnd-use Scenario Simulation In Catchments; Crooks and Naden 2007), which has been used extensively for modelling the potential impacts of climate change on river flows and flooding in relatively large catchments across Great Britain (e.g. Prudhomme et al. 2013a,b, Kay and Crooks 2014). The development of CLASSIC from a catchment-based model to a national model took advantage of the fact that the runoff-production parameters in CLASSIC are derived from gridded datasets of soils, landcover and topography. CLASSIC-GB can currently be run at a range of spatial resolutions, from $1 \mathrm{~km}$ up to $10 \mathrm{~km}$, aligned with the GB National Grid. 
The maximum time-step of the routing component has to be sufficiently small, relative to the spatial resolution, for stability of the kinematic wave routing scheme, but the main model time-step can be a multiple of the routing timestep. Here, to make best use of the RCM data, CLASSIC-GB is run with a $1 \mathrm{~km}$ spatial resolution and a 1-hour main time-step (20-minute routing time-step).

CLASSIC-GB requires gridded time-series of precipitation and potential evaporation (PE). If the snow module is implemented then gridded temperature time-series are also required, but this module is not used here as the focus on southern Britain means that snow is not a major influence on flows. A run of CLASSIC-GB is performed using observed precipitation and PE, to compare against the runs driven by RCM data. This observation-driven run uses $1 \mathrm{~km}$ daily total precipitation from CEH Gridded Estimates of Areal Rainfall (CEHGEAR; Keller et al. 2015) and 40km monthly total PE from the Met Office Rainfall and Evaporation Calculation System (MORECS; Hough et al. 1996). The data are temporally downscaled by dividing by the number of hydrological model time-steps in a data time-step, and the PE data are spatially downscaled by copying data from the $40 \mathrm{~km}$ grid down to the $1 \mathrm{~km}$ hydrological model grid (as Bell et al. (2012)).

\subsection{Regional Climate Model data}

Table 1 summarises the seven hydrological model runs performed, one using observed driving data and six using RCM data, and provides the precipitation and PE data sources and time-periods. The $1.5 \mathrm{~km} \mathrm{RCM}$ is a modified version of the UK Met Office weather forecast model (UKV), and the $12 \mathrm{~km} \mathrm{RCM}$ is a limited-area version of HadGEM3 (Moufouma-Okia and Jones 2015). Each $1.5 \mathrm{~km} \mathrm{RCM}$ run is nested in the equivalent $12 \mathrm{~km} \mathrm{RCM}$ run; the $1.5 \mathrm{~km} \mathrm{RCM}$ covers southern Britain (Figure 1) while the $12 \mathrm{~km}$ RCM covers Europe. The boundary conditions for the $12 \mathrm{~km}$ RCM runs are provided by either ERA-Interim reanalyses (ERA-driven) or an equivalent (Current or Future) GCM run (GCMdriven). Further RCM details are provided by Kendon et al. $(2012,2014)$.

Each RCM run provides hourly precipitation data. To drive CLASSIC-GB, the precipitation is converted from the RCM grid to the $1 \mathrm{~km}$ hydrological model grid. Conversion for the $1.5 \mathrm{~km}$ RCM uses area-weighting, while for the $12 \mathrm{~km} \mathrm{RCM}$ the data are disaggregated to the $1 \mathrm{~km}$ hydrological model grid by assigning fractions of the $12 \mathrm{~km}$ grid-box rainfall amount to $1 \mathrm{~km}$ grid-boxes according to the ratios in observed average annual rainfall patterns (Bell et al. 2007). The latter scaling allows a non-uniform spatial distribution of rainfall in each $12 \mathrm{~km}$ RCM grid-box, based on the observed rainfall distribution (e.g. allowing orographic enhancement); it does not act as a bias-correction. Note that the RCMs have a rotated lat-long grid so do not align with the GB national grid used by CLASSIC-GB.

The RCM runs do not provide the PE data required to drive CLASSIC-GB, so monthly $P E$ is estimated from other meteorological variables output by the RCMs, using the Penman-Monteith formula (Monteith 1965). A comparison of 
the ERA-driven RCM PE with MORECS PE (Rudd and Kay 2015) shows good correspondence, and also shows that the PE from the $1.5 \mathrm{~km}$ and $12 \mathrm{~km}$ RCMs is very similar. Here, the PE from the $12 \mathrm{~km}$ RCM runs is also used for the equivalent $1.5 \mathrm{~km}$ RCM runs (Table 1), to simplify the application and ensure that any differences in flow results are due only to differences in precipitation inputs. The $12 \mathrm{~km}$ RCM PE is temporally and spatially downscaled as for MORECS PE (Section 2.1).

Table 1 Summary of the seven hydrological model runs, with precipitation and PE data sources including the Met Office's RCM run names (5 characters starting with 'a').

\begin{tabular}{|c|c|c|c|c|}
\hline $\begin{array}{l}\text { Run } \\
\text { number }\end{array}$ & Description & $\begin{array}{l}\text { Precipitation } \\
\text { source }\end{array}$ & PE source & Time period \\
\hline 1 & $\begin{array}{l}\text { Observation- } \\
\text { driven (Obs) }\end{array}$ & $\begin{array}{l}\text { CEH-GEAR } \\
(1 \mathrm{~km})\end{array}$ & $\begin{array}{l}\text { MORECS } \\
(40 \mathrm{~km})\end{array}$ & Apr 1989-Dec 2008 \\
\hline 2 & $\begin{array}{l}\text { ERA-driven } \\
\text { Baseline } 12 \mathrm{~km}\end{array}$ & $\begin{array}{l}\text { ajtyr RCM } \\
(12 \mathrm{~km})\end{array}$ & $\begin{array}{l}\text { ajtyr RCM } \\
(12 \mathrm{~km})\end{array}$ & Apr 1989-Dec 2008 \\
\hline 3 & $\begin{array}{l}\text { ERA-driven } \\
\text { Baseline } 1.5 \mathrm{~km}\end{array}$ & $\begin{array}{l}\text { akigd RCM } \\
(1.5 \mathrm{~km})\end{array}$ & $\begin{array}{l}\text { ajtyr RCM } \\
(12 \mathrm{~km})\end{array}$ & Apr 1989-Nov 2008 \\
\hline 4 & $\begin{array}{l}\text { GCM-driven } \\
\text { Current } 12 \mathrm{~km}\end{array}$ & $\begin{array}{l}\text { alqtj RCM } \\
(12 \mathrm{~km})\end{array}$ & $\begin{array}{l}\text { alqtj RCM } \\
(12 \mathrm{~km})\end{array}$ & Apr 1996-Nov 2009 \\
\hline 5 & $\begin{array}{l}\text { GCM-driven } \\
\text { Current } 1.5 \mathrm{~km}\end{array}$ & $\begin{array}{l}\text { alxmc RCM } \\
(1.5 \mathrm{~km})\end{array}$ & $\begin{array}{l}\text { alqtj RCM } \\
(12 \mathrm{~km})\end{array}$ & May 1996-Nov 2009 \\
\hline 6 & $\begin{array}{l}\text { GCM-driven } \\
\text { Future } 12 \mathrm{~km}\end{array}$ & $\begin{array}{l}\text { alqtk RCM } \\
(12 \mathrm{~km})\end{array}$ & $\begin{array}{l}\text { alqtk RCM } \\
(12 \mathrm{~km})\end{array}$ & $\begin{array}{l}\text { As Run } 4 \text { but for } 13 \text {-year period } \\
\text { in } \sim 2100 \text { with RCP8.5 emissions }\end{array}$ \\
\hline 7 & $\begin{array}{l}\text { GCM-driven } \\
\text { Future } 1.5 \mathrm{~km}\end{array}$ & $\begin{array}{l}\text { alxme RCM } \\
(1.5 \mathrm{~km})\end{array}$ & $\begin{array}{l}\text { alqtk RCM } \\
(12 \mathrm{~km})\end{array}$ & $\begin{array}{l}\text { As Run } 5 \text { but for } 13 \text {-year period } \\
\text { in } \sim 2100 \text { with RCP } 8.5 \text { emissions }\end{array}$ \\
\hline
\end{tabular}

\subsection{Analysis methods}

\subsubsection{Use of ERA-driven RCM data}

Data from the $12 \mathrm{~km}$ and $1.5 \mathrm{~km}$ ERA-driven RCM runs are used to drive CLASSIC-GB (Apr 1989-Nov 2008; Table 1). The resulting daily mean flows are output for points on the $1 \mathrm{~km}$ grid corresponding to 32 gauged catchments (Table 2 and Figure 1). These catchments are the southern-GB subset of the 54 catchments used to assess CLASSIC-GB (Crooks et al. 2014), which were selected to cover a range of climatic and soil properties and catchment areas. The RCM-simulated flows are compared to both flows simulated using observed input data to drive CLASSIC-GB, and gauged (observed) flows for these catchments (from the National River Flow Archive, www.ceh.ac.uk/data/nrfa/). The comparison only looks at flows for Jan 1990-Nov 2008, thus allowing a spin-up period from Apr 1989 (which overlaps with the climate model spin-up, Apr-Nov 1989). As the development of weather features in the ERA-driven RCMs is not expected to directly follow the observed weather over the period, the comparison of resulting flows is done mainly in terms of flow duration and flood frequency curves, thus comparing the statistical characteristics of the flows rather than day-to-day equivalence. 
Table 2 Details of the 32 example catchments.

\begin{tabular}{|c|c|c|c|c|c|}
\hline $\begin{array}{l}\text { Station } \\
\text { number }\end{array}$ & River@ Location & $\begin{array}{c}\text { Area } \\
\left(\mathrm{km}^{2}\right)\end{array}$ & $\begin{array}{c}\text { SAAR }_{61-90} \\
(\mathrm{~mm})\end{array}$ & $\begin{array}{c}\text { Altitude } \\
\text { range }(\mathrm{m})\end{array}$ & $\begin{array}{c}\text { BFI } \\
(-)\end{array}$ \\
\hline 27021 & Don@ Doncaster & 1256 & 799 & $4-543$ & 0.56 \\
\hline 28022 & Trent@ North Muskham & 8231 & 747 & $5-634$ & 0.65 \\
\hline 28066 & Cole@ Coleshill & 130 & 722 & 79-202 & 0.43 \\
\hline 28085 & Derwent @ St Mary's Bridge & 1054 & 1012 & $44-634$ & 0.63 \\
\hline 33019 & Thet @ Melford Bridge & 316 & 620 & $11-71$ & 0.78 \\
\hline 33026 & Bedford Ouse @ Offord & 2570 & 609 & $11-247$ & 0.50 \\
\hline 36006 & Stour@ Langham & 578 & 580 & $6-128$ & 0.52 \\
\hline 39001 & Thames@Kingston & 9948 & 706 & $5-330$ & 0.63 \\
\hline 39006 & Windrush@ Newbridge & 363 & 743 & $63-317$ & 0.86 \\
\hline 39016 & Kennet@ Theale & 1038 & 759 & $43-296$ & 0.88 \\
\hline 39020 & Coln@Bibury & 107 & 820 & $101-330$ & 0.93 \\
\hline 39034 & Evenlode @ Cassington Mill & 430 & 691 & $60-267$ & 0.71 \\
\hline 39081 & Ock@ Abingdon & 234 & 639 & $51-260$ & 0.64 \\
\hline 40003 & Medway@ Teston & 1256 & 744 & $7-268$ & 0.40 \\
\hline 40011 & Great Stour@ Horton & 345 & 747 & $13-196$ & 0.69 \\
\hline 42004 & Test@ Broadlands & 1040 & 790 & $10-296$ & 0.94 \\
\hline 43021 & Avon@ Knapp Mill & 1706 & 810 & $1-294$ & 0.86 \\
\hline 45001 & Exe@ Thorveton & 601 & 1295 & $26-514$ & 0.50 \\
\hline 45005 & Otter@Dotton & 202 & 976 & $15-302$ & 0.53 \\
\hline 47001 & Tamar@ Gunnislake & 917 & 1216 & $8-580$ & 0.46 \\
\hline 50006 & Mole@ Woodleigh & 327 & 1307 & $48-490$ & 0.47 \\
\hline 53018 & Avon@ Bathford & 1552 & 817 & $18-304$ & 0.57 \\
\hline 54001 & Severn@Bewdley & 4325 & 913 & $17-826$ & 0.53 \\
\hline 54002 & Avon@ Evesham & 2210 & 654 & $20-317$ & 0.52 \\
\hline 54029 & Teme @ Knightsford Bridge & 1480 & 818 & $21-545$ & 0.55 \\
\hline 54057 & Severn@ Haw Bridge & 9895 & 792 & $11-826$ & 0.56 \\
\hline 55023 & Wye@Redbrook & 4010 & 1011 & $9-749$ & 0.54 \\
\hline 56001 & Usk @ Chain Bridge & 912 & 1363 & $23-885$ & 0.50 \\
\hline 60003 & Taf @ Clog-y-Fran & 217 & 1420 & 9-392 & 0.55 \\
\hline 62001 & Teifi@ Glan Teifi & 894 & 1382 & $66-592$ & 0.54 \\
\hline 67015 & Dee@ Manley Hall & 1013 & 1369 & $25-878$ & 0.54 \\
\hline 68005 & Weaver@Audlem & 207 & 719 & $45-221$ & 0.52 \\
\hline
\end{tabular}

SAAR61-90 - standard average annual rainfall for 1961-1990;

$\mathrm{BFI}$ - baseflow index (proportion of flow from stored sources like groundwater)

The flow duration curve is calculated from the flow time-series for a catchment by ranking the flows in descending order and selecting the flow $Q_{p}$ corresponding to each percentile point $p$ between 1 and $100 ; Q_{p}$ is thus the flow equalled or exceeded $p \%$ of the time. Several performance measures (adapted from Yilmaz et al. (2008)) are used to quantify different aspects of the fit of simulated and observed flow duration curves $\left(Q_{p}\right.$ and $O_{p}$ respectively); percentage bias in low flow volume (Ifv), median flow ( $m d f)$, and high flow volume $(h f v)$. These are calculated as

$$
\begin{gathered}
l f v=100 \frac{\sum_{p=70}^{95}\left[f\left(Q_{p}\right)-f\left(O_{p}\right)\right]}{\sum_{p=70}^{95} f\left(O_{p}\right)} \\
m d f=100 \frac{f\left(Q_{50}\right)-f\left(O_{50}\right)}{f\left(O_{50}\right)} \\
h f v=100 \frac{\sum_{p=1}^{2}\left[f\left(Q_{p}\right)-f\left(O_{p}\right)\right]}{\sum_{p=1}^{2} f\left(O_{p}\right)}
\end{gathered}
$$


where the function $f()$ is taken as sqrt(), so as not to put too much emphasis on bias in very high flow values. The low flow volume bias Ifv only goes up to the $95^{\text {th }}$ percentile flow (from the $70^{\text {th }}$ ) so as not to include very low flow values, which can be more severely affected by abstractions, effluent returns etc.

The flood frequency curve is calculated by first extracting annual maxima (AM) from the flow time-series for a catchment (for water years, $1^{\text {st }}$ Oct- $30^{\text {th }}$ Sep). A generalised logistic (GLO) distribution is then fitted to the AM using the method of L-moments (Robson and Reed 1999). The three parameters of the fitted GLO (location $\xi$, scale $\alpha$, shape $k$ ) can then be used to calculate flows $Q_{T}$ corresponding to specific return periods $T$ using $Q_{T}=\xi+(\alpha / k)\left(1-(T-1)^{-k}\right)$, to produce a flood frequency curve. The fit of simulated and observed flood frequency curves ( $Q_{T}$ and $O_{T}$ respectively) is averaged over 2, 5 and 10-year return periods, using

$$
f f r=\frac{100}{3} \sum_{T \in\{2,5,10\}} \frac{f\left(Q_{T}\right)-f\left(O_{T}\right)}{f\left(O_{T}\right)}
$$

where $f()$ is as above. Higher return periods are not included in ffr due to the limited period of ERA-driven RCM data available (about 19 years; Table 1). For all four measures of fit, values closer to zero indicate better performance.

\subsubsection{Use of GCM-driven RCM data}

Data from the $12 \mathrm{~km}$ and $1.5 \mathrm{~km}$ GCM-driven Current and Future RCM runs are used to drive CLASSIC-GB (Table 1). For these runs, instead of outputting flow time-series corresponding to specific gauged catchments, as for the ERA-driven runs, the outputs are $1 \mathrm{~km}$ grids of AM (derived from gridded hourly mean flows). These are used to calculate grids of the flows $Q_{T}$ corresponding to specific return periods $T$ (via the fitting of GLOs as in Section 2.3.1) for $T=2,5$ and 10 years (as for ffr, higher return periods are not used due to the limited data period of about 13 years; Table 1). Percentage changes are then calculated between the return period flows for corresponding Current and Future runs.

As the $1.5 \mathrm{~km}$ and $12 \mathrm{~km}$ RCMs show greater precipitation differences in summer than winter, the same analyses are done for seasonal maxima as for AM, for the four standard seasons; winter (Dec-Feb), spring (Mar-May), summer (JunAug) and autumn (Sep-Nov).

\section{Results}

\subsection{Performance using ERA-driven RCM runs}

Figure 2 shows a comparison of gauged flows with flows simulated using observed data and $12 \mathrm{~km}$ and $1.5 \mathrm{~km}$ ERA-driven RCM data, for two catchments; 39081 (Ock at Abingdon) and 55023 (Wye at Redbrook) (Table 2). The comparison is presented as flow time-series (for 2006-2007), and as flow duration and flood frequency curves (calculated from flow time-series for 19902008). Flows for the Ock are generally too high when simulated using data from 
either ERA-driven RCM run, leading to flow duration curves and flood frequency curves that are over-estimated compared to those from gauged flows or flows simulated using observed data. By contrast, flows for the Wye simulated using RCM data are a much better match to gauged flows, especially for the flow duration curve. In both catchments, the curves simulated using data from the $1.5 \mathrm{~km} \mathrm{RCM}$ are higher than those using data from the $12 \mathrm{~km} \mathrm{RCM}$.

Flow time-series (Figure 2) also show that the high flows gauged in July 2007 (when much of southern Britain experienced severe flooding) are not captured by the ERA-driven RCM data for either catchment. However, for the Ock the $1.5 \mathrm{~km}$ RCM data generate a peak flow of similar size to that gauged in July 2007, but occurring about a month earlier. The $12 \mathrm{~km}$ RCM produces no such peak in the year 2007. Chan et al. (2013) comment on the failure of the RCM runs to capture the high precipitation totals of summer 2007, despite being driven by re-analysis boundary conditions. They state that, since re-analysis data are only used at the edge of the European domain, an exact agreement in the positioning of events over Britain should not be expected, either between RCMs and observations or between nested RCMs (due to internal variability of the models). Hence performance assessments are hereafter based on statistical comparisons using the four measures given in Section 2.3.1 (low flow volume Ifv, median flow $m d f$, high flow volume $h f v$ and flood frequency ffr).

The performance measures for all 32 example catchments (Figure 3) show that, compared to the use of observed inputs, the $12 \mathrm{~km}$ RCM performs relatively well across the full flow range in many catchments, but the $1.5 \mathrm{~km}$ RCM generally performs less well than the $12 \mathrm{~km}$ RCM. More catchments have positive than negative biases using RCM data, and where the $12 \mathrm{~km}$ RCM shows positive bias the $1.5 \mathrm{~km}$ RCM often shows a more accentuated positive bias, especially for flood frequency fit. This is consistent with the mean precipitation bias being higher in the $1.5 \mathrm{~km}$ RCM than the $12 \mathrm{~km}$ RCM (Chan et al. 2013); a known weakness of convection-permitting models (Kendon et al. 2012).

Mapping the performance measures (Figure 4) shows clear spatial patterns for the $1.5 \mathrm{~km}$ RCM, with generally positive biases in the east and negative biases in the west. These patterns are either less clear or not present for the $12 \mathrm{~km}$ RCM and for observed inputs. The patterns are especially pronounced for high flows (volumes and flood frequency), and are consistent with the spatial patterns found in precipitation biases for the $1.5 \mathrm{~km} \mathrm{RCM}$, which are more pronounced than for the 12km RCM (Fig. 3 of Chan et al. 2013).

Plots of the performance measures against catchment properties (Figure 5) show that, while performance is relatively independent of catchment area and baseflow index, it is poorer for catchments with low annual rainfall or low altitude. In Britain, such catchments are generally located in the south and east of the country, so this is consistent with the spatial patterns of performance (Figure 4), thus the lower performance in such catchments is likely to be due to the coincident spatial patterns of rainfall bias rather than catchment properties. 


\subsection{Changes in flood peaks using GCM-driven RCM runs}

Percentage changes in 10-year return period flood peaks, simulated using data from corresponding Current and Future RCM runs, show some clear differences between the $12 \mathrm{~km}$ and $1.5 \mathrm{~km} \mathrm{RCMs} \mathrm{(Figure} \mathrm{6),} \mathrm{both} \mathrm{in} \mathrm{terms} \mathrm{of} \mathrm{spatial} \mathrm{patterns}$ and histograms summarising changes. The biggest differences are seen in spring, where the changes are often higher when simulated using data from the $1.5 \mathrm{~km} \mathrm{RCM}$ than from the $12 \mathrm{~km}$ RCM. Similar but less pronounced differences are seen for changes in winter and annual peaks. This is consistent with the greater intensification of winter daily precipitation extremes seen in the $1.5 \mathrm{~km}$ RCM than the $12 \mathrm{~km} \mathrm{RCM} \mathrm{(Fig.} \mathrm{3d} \mathrm{of} \mathrm{Chan} \mathrm{et} \mathrm{al.} \mathrm{2014),} \mathrm{and} \mathrm{the} \mathrm{locations} \mathrm{of} \mathrm{the}$ largest increase, over parts of Wales and the north-west, are also consistent (Fig. 1d of Chan et al. 2014).

The least difference in the percentage changes in 10-year return period flood peaks is seen for summer peaks, despite summer being the season showing the biggest differences in sub-daily precipitation projections for the $12 \mathrm{~km}$ and $1.5 \mathrm{~km}$ RCMs (Fig. 3 of Kendon et al. 2014). This illustrates the low influence that summer sub-daily precipitation has on flood peaks in most of the catchments being modelled here (that is, only those river points with drainage areas above $50 \mathrm{~km}^{2}$, so not very small, flashy catchments). Histograms stratified by catchment area $\left(\right.$ Area $<100 \mathrm{~km}^{2} ; 100 \mathrm{~km}^{2}<$ Area $<500 \mathrm{~km}^{2}$; Area $\left.>500 \mathrm{~km}^{2}\right)$ show little difference to the full histograms in Figure 6, even for summer (not shown). Results for 2- and 5-year return period flood peaks are similar to those for the 10-year return period, although the percentage changes are generally smaller for lower return periods (not shown).

\section{Discussion and conclusions}

Although Regional Climate Models (RCMs) are a significant improvement upon Global Climate Models (GCMs) in terms of representation of rainfall patterns (e.g. Durman et al. 2001), their usual spatial scale (tens of kilometres) means that there are still deficiencies, particularly with smaller scale processes like convective storms that require parameterisation schemes (e.g. Molinari and Dudek 1992). Recently, the first decadal-length runs of RCMs with convectionpermitting scales were performed. The aims here were to test the performance of data from these RCMs when used to drive hydrological models to simulate river flows, and to assess any differences in projections of flood change using data from the finer scale RCM runs compared to more usual scale runs.

The results using ERA-driven RCM runs (1.5km RCM nested in a $12 \mathrm{~km}$ RCM driven by ERA-Interim boundary conditions for 1989-2008) show that the $1.5 \mathrm{~km}$ RCM generally performs worse than the $12 \mathrm{~km}$ RCM for simulating river flows in 32 example catchments in southern Britain, with a clear east/west pattern of bias. This is consistent with patterns of mean bias shown in the RCM precipitation data. Despite the $1.5 \mathrm{~km}$ RCM having much more realistic hourly rainfall characteristics, it has a tendency for too intense heavy rainfall. This is a 
current inherent weakness of convection-permitting models (Kendon et al. 2012) and it is this mean bias which seems to be dominating the fluvial results here. This suggests that, currently, very high resolution RCMs are not automatically more reliable for hydrological modelling than lower resolution RCMs, especially for large-scale river flooding. Improvements are needed if finer resolution RCMs are to become more routinely used, although it is possible that greater benefits of the $1.5 \mathrm{~km} \mathrm{RCM}$ may be seen in smaller catchments.

The results using GCM-driven RCM runs $(1.5 \mathrm{~km}$ RCM nested in a $12 \mathrm{~km}$ RCM nested in a GCM, for the current climate and a potential future climate) show clear differences in projected changes in flood peaks. In all seasons except summer the $1.5 \mathrm{~km}$ RCM tends towards larger increases in flood peaks than the $12 \mathrm{~km} \mathrm{RCM}$, with differences most pronounced for spring and winter. This is consistent with greater increases in winter daily precipitation extremes in the $1.5 \mathrm{~km}$ RCM. However, the robustness of this result is unclear, both because of the higher biases shown in the $1.5 \mathrm{~km} \mathrm{RCM} \mathrm{and} \mathrm{because} \mathrm{only} \mathrm{one} \mathrm{set} \mathrm{of} \mathrm{such}$ runs has so far been performed, for a relatively short period ( $\sim 13$ years), so the effects of natural variability may be a significant factor.

The apparent insensitivity of changes in summer peak flows, despite the $1.5 \mathrm{~km}$ $\mathrm{RCM}$ showing significantly greater increases in sub-daily rainfall intensity than the $12 \mathrm{~km} \mathrm{RCM}$, may be due to the lower limit on the drainage area of rivers mapped $\left(50 \mathrm{~km}^{2}\right)$. It is possible that very small flashy catchments would show different results, but such catchments would be better modelled with a finer scale gridded model than that applied here, or even with a catchment-based hydrological model which can be setup and calibrated specifically for the details of small catchments. In particular, small urban catchments are more likely to be adversely affected by increases in intensity of sub-daily rainfall in summer, in terms of both river (fluvial) flooding and surface water (pluvial) flooding, but modelling the flow of water in such catchments is complex due to the presence of artificial drainage channels etc.

Future plans involve further investigation of flood projections, including using the RCM data applied here with a new modelling approach developed for surface water flood forecasting (Cole et al. 2013) which was trialled operationally during the Glasgow 2014 Commonwealth Games (Moore et al. 2015; Speight et al. 2015). Rather than relying on exceedance of rainfall thresholds, as many existing pluvial flood warning systems do, the new approach uses gridded surface runoff estimates from the Grid-to-Grid model (Bell et al. 2009), which is also used for operational fluvial flood forecasting in Britain (Price et al. 2012). The approach will be used to investigate potential changes in the frequency of pluvial flooding, using the Current and Future $1.5 \mathrm{~km}$ and $12 \mathrm{~km}$ RCM data, compared to changes projected just from rainfall thresholds. In addition, finer resolution RCM runs are currently being performed for the rest of Britain, so it will be interesting to see if the results shown here for southern Britain apply elsewhere. 


\section{Acknowledgements}

Thanks to the UK Met Office for access to the RCM data, and to three anonymous reviewers of the manuscript. The work was funded by the Natural Hazards science area of the NERC-CEH Water and Pollution Science programme. EJK and RGJ gratefully acknowledge funding from the DECC/Defra Met Office Hadley Centre Climate Programme (GA01101).

\section{References}

Addor N, Seibert J (2014). Bias correction for hydrological impact studies - beyond the daily perspective. Hydrological Processes, 28:4823-4828.

Ban N, Schmidli J, Schär C. (2014). Evaluation of the convection-resolving regional climate modeling approach in decade-long simulations. Journal of Geophysical Research: Atmospheres, 119:7889-7907.

Bayliss AC, Jones RC (1993). Peaks-over-threshold flood database: Summary statistics and seasonality. IH Report No. 121, Institute of Hydrology, Wallingford.

Bell VA, Kay AL, Cole SJ et al. (2012). How might climate change affect river flows across the Thames Basin? An area-wide analysis using the UKCP09 Regional Climate Model ensemble. Journal of Hydrology, 442-443:89-104.

Bell VA, Kay AL, Jones RG, Moore RJ (2007). Development of a high resolution grid-based river flow model for use with regional climate model output. Hydrology and Earth System Sciences, 11:532-549.

Bell VA, Kay AL, Jones RG, Moore RJ, Reynard NS (2009). Use of soil data in a grid-based hydrological model to estimate spatial variation in changing flood risk across the UK. Journal of Hydrology, 377:335-350.

Chan SC, Kendon EJ, Fowler HJ et al. (2013). Does increasing the spatial resolution of a regional climate model improve the simulated daily precipitation? Climate Dynamics, 41:14751495.

Chan SC, Kendon EJ, Fowler HJ et al. (2014). Projected increases in summer and winter UK sub-daily precipitation extremes from high-resolution regional climate models. Environmental Research Letters, 9:084019.

Chiverton A, Hannaford J, Holman I et al. (2015). Which catchment characteristics control the temporal dependence structure of daily river flows? Hydrological Processes, 29:1353-1369.

Cole SJ, Moore RJ, Aldridge T et al. (2013). Real-time hazard impact modelling of surface water flooding: some UK developments. In: Butler D et al. (eds.) Proceedings of the International Conference on Flood Resilience: Experiences in Asia and Europe (ICFR 2013). University of Exeter.

Crooks SM, Kay AL, Davies HN, Bell VA (2014). From Catchment to National Scale RainfallRunoff Modelling: Demonstration of a Hydrological Modelling Framework. Hydrology, 1:63-88.

Crooks SM, Naden PS (2007). CLASSIC: a semi-distributed modelling system. Hydrology and Earth System Sciences, 11:516-531.

Dankers R, Feyen L (2008). Climate change impact on flood hazard in Europe: An assessment based on high-resolution climate simulations. Journal of Geophysical Sciences, 113:D19105. 
Durman CF, Gregory JM, Hassell DC et al. (2001). A comparison of extreme European daily precipitation simulated by a global and a regional climate model for present and future climates. Quarterly Journal of the Royal Meteorological Society, 127:1005-1015.

Ehret U, Zehe E, Wulfmeyer V et al. (2012). Should we apply bias correction to global and regional climate model data? Hydrology and Earth System Sciences, 16:3391-3404.

Fischer EM, Knutti R (2013). Robust projections of combined humidity and temperature extremes. Nature Climate Change, 3:126-130.

Graham LP, Hageman S, Jaun S, Beniston M (2007). On interpreting hydrological change from regional climate models. Climatic Change, 81:97-122

Hewitson B, Janetos AC, Carter TR et al. (2014). Regional context. In: Climate Change 2014: Impacts, Adaptation, and Vulnerability. Part B: Regional Aspects. Contribution of Working Group II to the Fifth Assessment Report of the Intergovernmental Panel on Climate Change [Barros VR et al. (eds.)]. Cambridge University Press, Cambridge, United Kingdom and New York, USA, 1133-1197.

Hough M, Palmer S, Weir A et al. (1996). The Meteorological Office Rainfall and Evaporation Calculation System: MORECS version 2.0 (1995). An update to Hydrological Memorandum 45, The Met. Office, Bracknell.

Huang S, Krysanova V, Hatterman FF (2014). Does bias correction increase reliability of flood projections under climate change? A case study of large rivers in Germany. International Journal of Climatology, 34:3780-3800.

Kay AL, Bell VA, Blyth EM et al. (2013). A hydrological perspective on evaporation: historical trends and future projections in Britain. Journal of Water and Climate Change, 4:193-208.

Kay AL, Crooks SM (2014). An investigation of the effect of transient climate change on snowmelt, flood frequency and timing in northern Britain. International Journal of Climatology, 34:3368-3381.

Kay AL, Jones DA (2012a). Transient changes in flood frequency and timing in Britain under potential projections of climate change. International Journal of Climatology, 32:489-502.

Kay AL, Jones RG (2012b). Comparison of the use of alternative UKCP09 products for modelling the impacts of climate change on flood frequency. Climatic Change, 114:211-230.

Keller VDJ, Tanguy M, Prosdocimi I et al (2015). CEH-GEAR: $1 \mathrm{~km}$ resolution daily and monthly areal rainfall estimates for the UK for hydrological use. Earth System Science Data Discussions, 8:83-112.

Kendon EJ, Roberts NM, Fowler HJ et al. (2014). Heavier summer downpours with climate change revealed by weather forecast resolution model. Nature Climate Change, 4:570-576.

Kendon EJ, Roberts NM, Senior CA, Roberts MJ (2012). Realism of rainfall in a very highresolution Regional Climate Model. Journal of Climate, 25:5791-5806.

Kjeldsen TR (2007). The revitalised FSR/FEH rainfall-runoff method. Flood Estimation Handbook Supplementary Report No. 1. Centre for Ecology \& Hydrology, UK.

Molinari J, Dudek M (1992). Parameterization of convective precipitation in mesoscale numerical models: a critical review. Mon. Weather Rev., 120:326-344. 
Monteith JL (1965). Evaporation and environment. Symposia of the Society for Experimental Biology, 19:205-234.

Moore RJ, Cole SJ, Dunn S et al. (2015). Surface water flood forecasting for urban communities. CREW report CRW2012_03, 32pp.

Moufouma-Okia W, Jones $R$ (2015). Resolution dependence in simulating the African hydroclimate with the HadGEM3-RA Regional Climate Model. Climate Dynamics, 44:609-632.

Price D, Hudson K, Boyce G et al. (2012). Operational use of a grid-based model for flood forecasting. Water Management, 165:65-77.

Prudhomme C, Crooks S, Kay AL, Reynard NS (2013a). Climate change and river flooding: Part 1 Classifying the sensitivity of British catchments. Climatic Change, 119:933-948.

Prudhomme C, Dadson S, Morris D et al. (2012). Future Flows Climate: an ensemble of 1-km climate change projections for hydrological application in Great Britain. Earth System Science Data, 4:143-148.

Prudhomme C, Haxton T, Crooks S et al. (2013b). Future Flows Hydrology: an ensemble of daily river flow and monthly groundwater levels for use for climate change impact assessment across Great Britain. Earth System Science Data, 5:101-107.

Riahi K, Rao S, Krey V et al. (2011). RCP 8.5-A scenario of comparatively high greenhouse gas emissions. Climatic Change, 109:33-57.

Robson AJ, Reed DW (1999). Statistical procedures for flood frequency estimation. Vol. 3, Flood Estimation Handbook. Institute of Hydrology, Wallingford, UK.

Rudd AC, Kay AL (2015). Use of very high resolution climate model data for hydrological modelling: estimation of potential evaporation. Hydrology Research, doi:10.2166/nh.2015.028.

Smith A, Bates P, Freer J, Wetterhall F (2014). Investigating the application of climate models in flood projection across the UK. Hydrological Processes, 28:2810-2823.

Speight L, Cole SJ, Moore RJ et al. (2015). Developing surface water flood forecasting capabilities in Scotland: an operational pilot for the 2014 Commonwealth Games in Glasgow. Journal of Flood Risk Management, under re-review.

Yilmaz KK, Gupta HV, Wagener T (2008). A process-based diagnostic approach to model evaluation: Application to the NWS distributed hydrologic model. Water Resources Research, 44:W09417. 


\section{Figures}

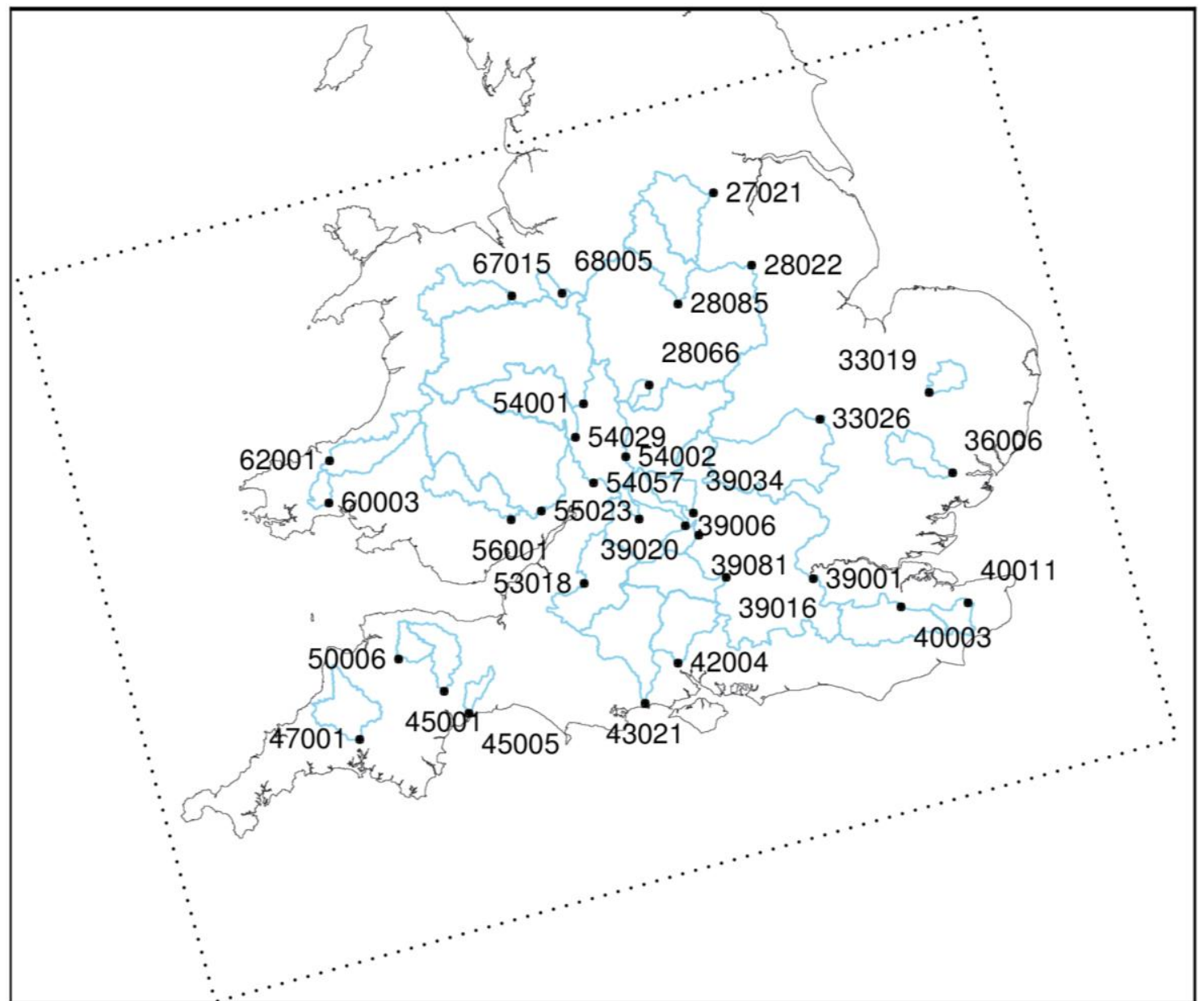

Figure 1 Map showing the locations and outlet points of the 32 example catchments in southern Britain (Table 2) and the region covered by the $1.5 \mathrm{~km}$ RCM (dotted rectangle). 

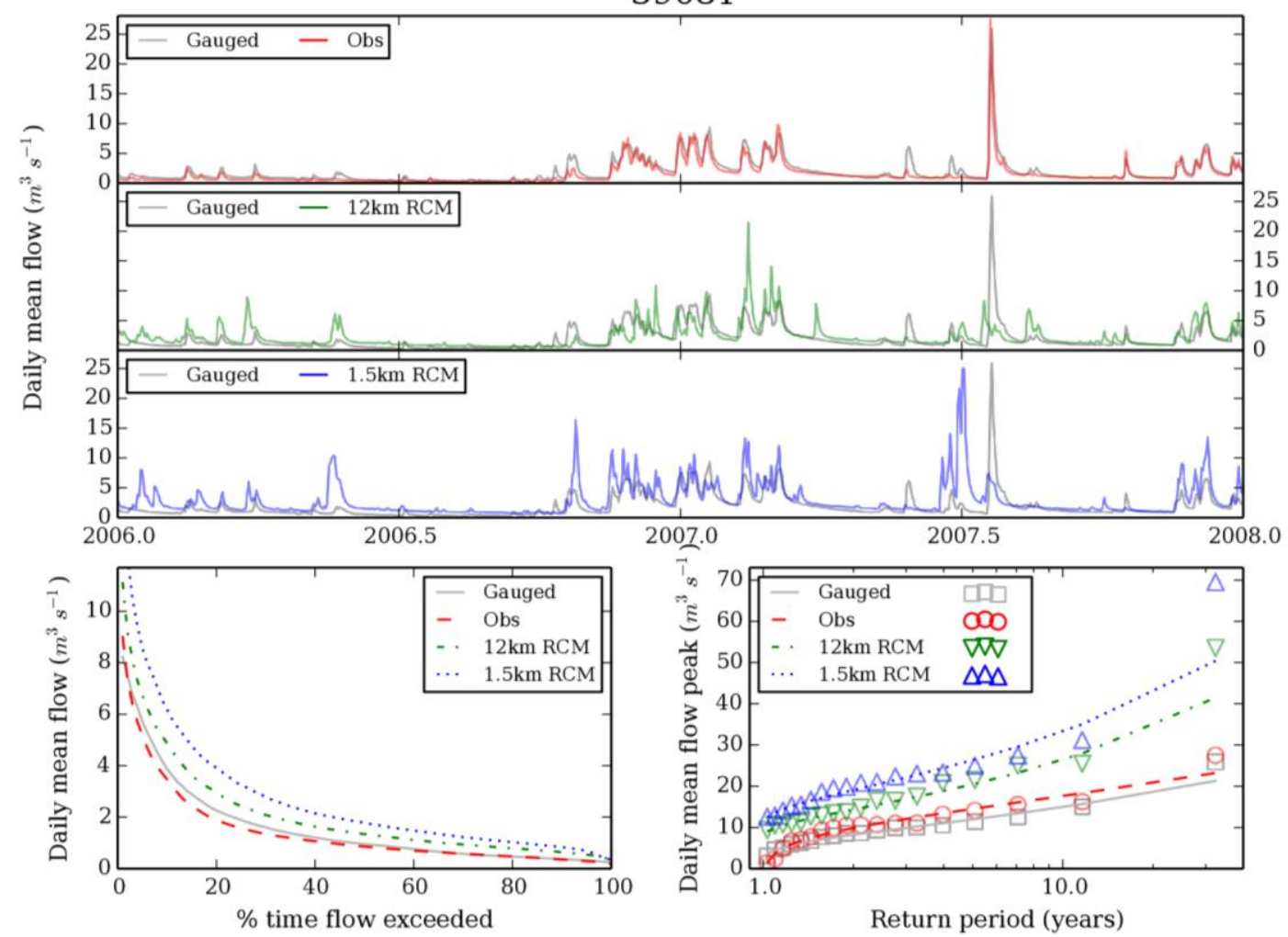

55023
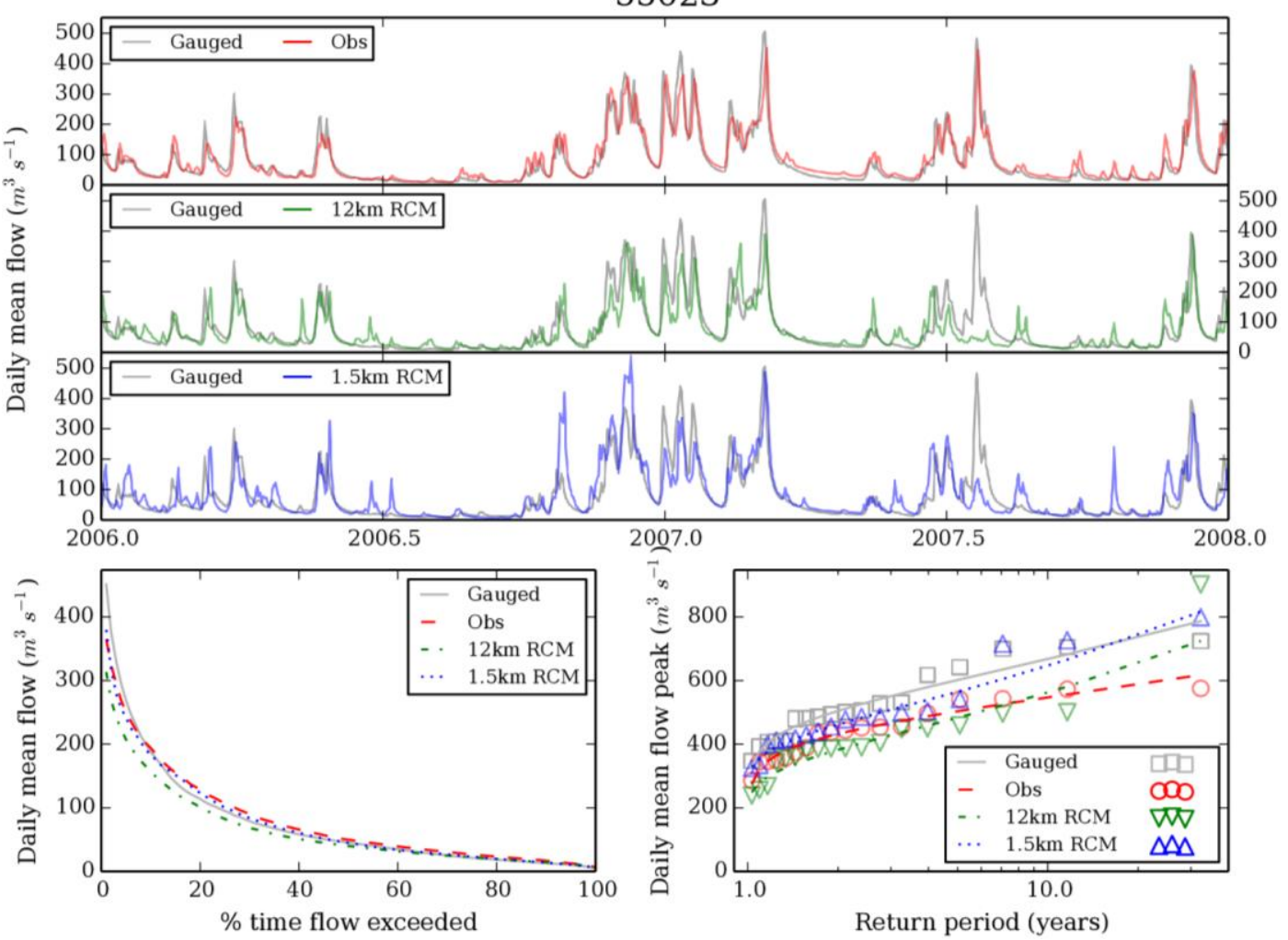

Figure 2 Gauged flow time-series, flow duration curves and flood frequency curves (grey) compared to those simulated using observed data (red), $12 \mathrm{~km} \mathrm{RCM} \mathrm{data} \mathrm{(green)} \mathrm{and} 1.5 \mathrm{~km} \mathrm{RCM} \mathrm{data} \mathrm{(blue)} \mathrm{for} \mathrm{two} \mathrm{of}$ the example catchments; 39081 (top) and 55023 (bottom) (Table 2). 


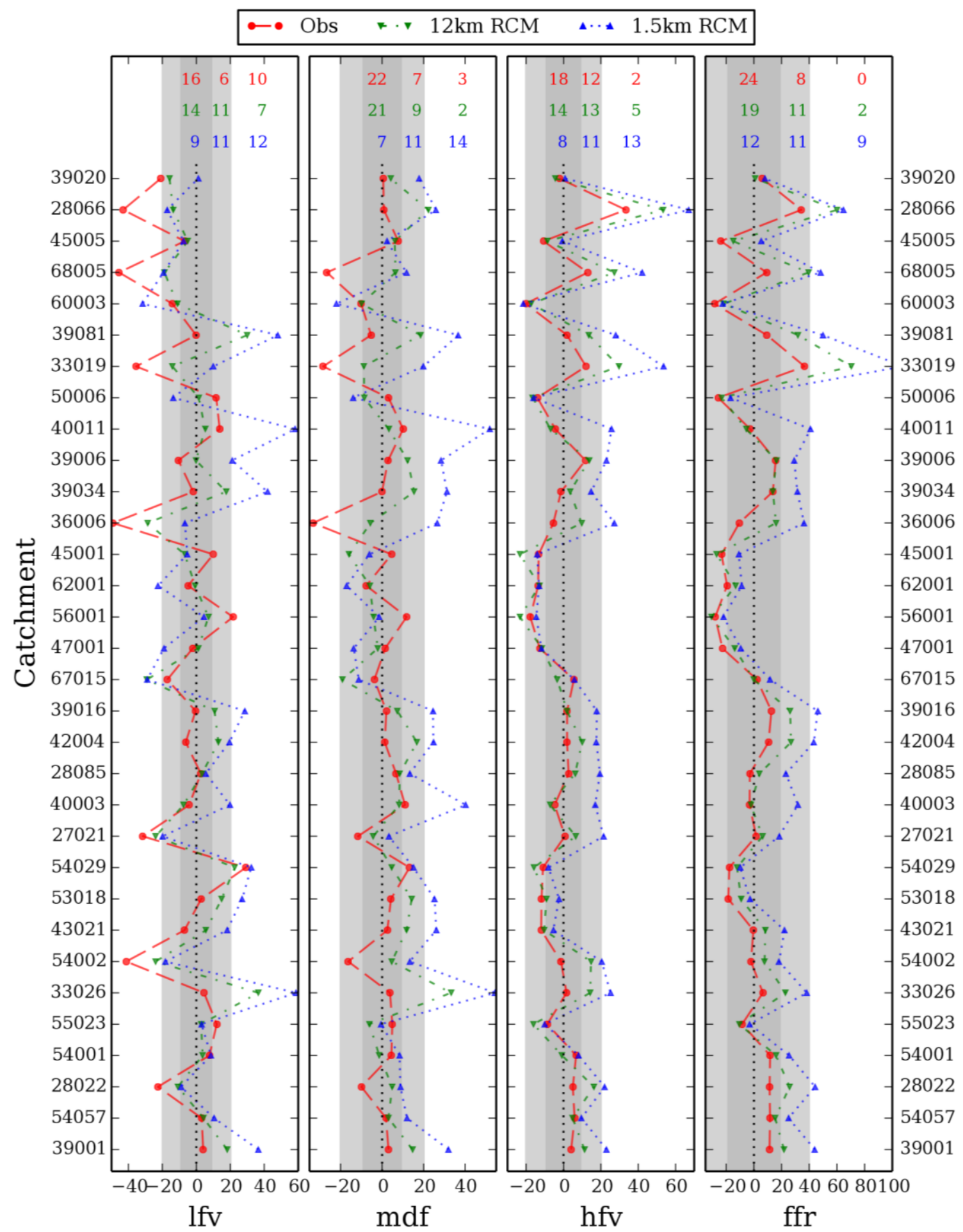

Figure 3 Performance of the $12 \mathrm{~km} \mathrm{RCM} \mathrm{(green)} \mathrm{and} 1.5 \mathrm{~km}$ RCM (blue) for simulating flows in the 32 example catchments, compared to using observed inputs (red), in terms of the fit of low flow volumes (Ifv), median flows ( $m d f)$, high flow volumes $(h f v)$ and flood frequency curves (ffr). The catchments are ordered by area (smallest at the top). The shading shows performance bands (dark grey - best, to white - worst), and the number of catchments in each band for each simulation is presented at the top. 

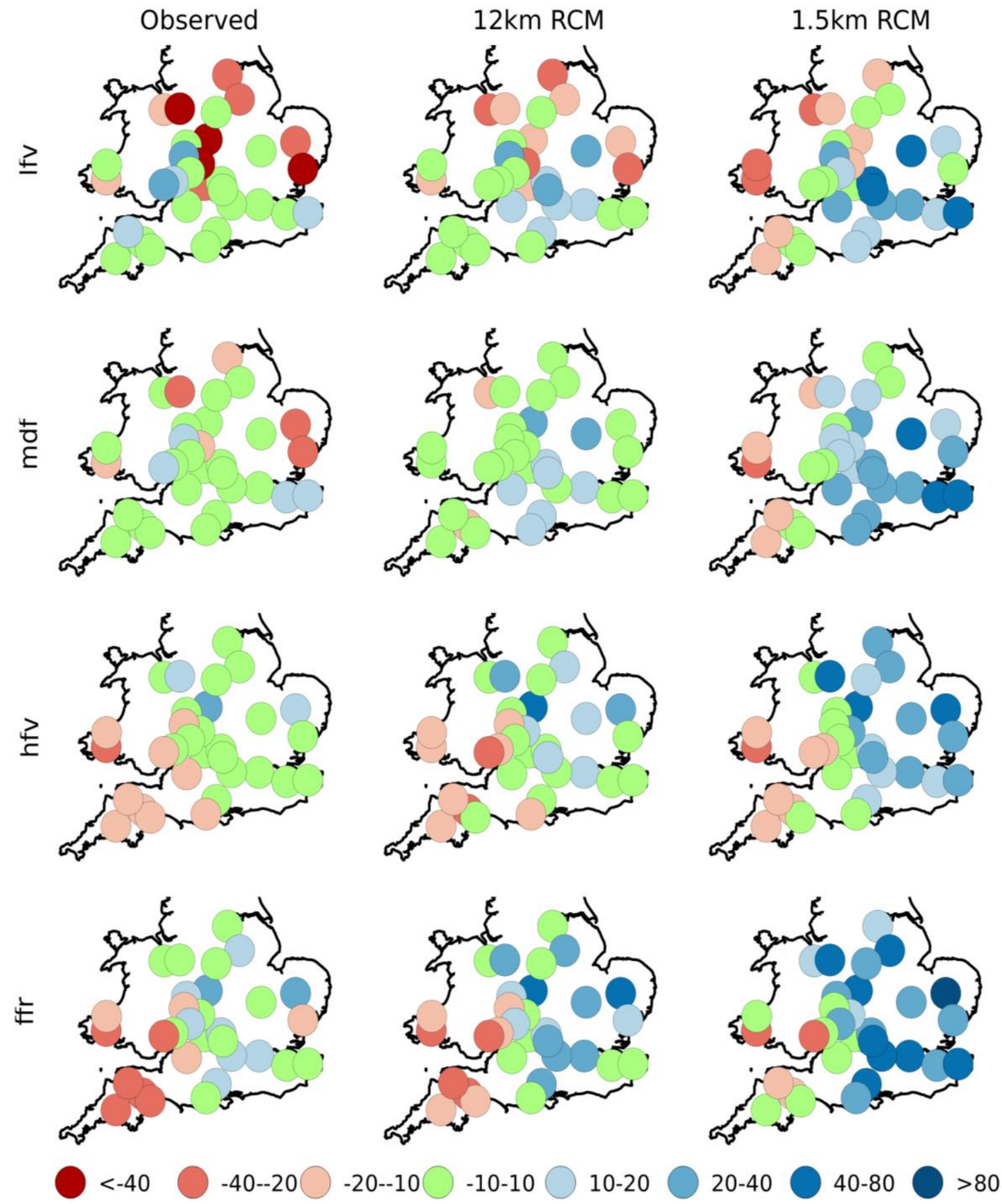

Figure 4 Maps of the four performance measures (Ifv, $m d f$, hfv, ffr), using observed inputs (left) and inputs from the $12 \mathrm{~km} \mathrm{RCM} \mathrm{(middle)} \mathrm{and} 1.5 \mathrm{~km}$ RCM (right). Circles are located at the outlets of the 32 example catchments, and coloured by the value of the performance measure (see key). 


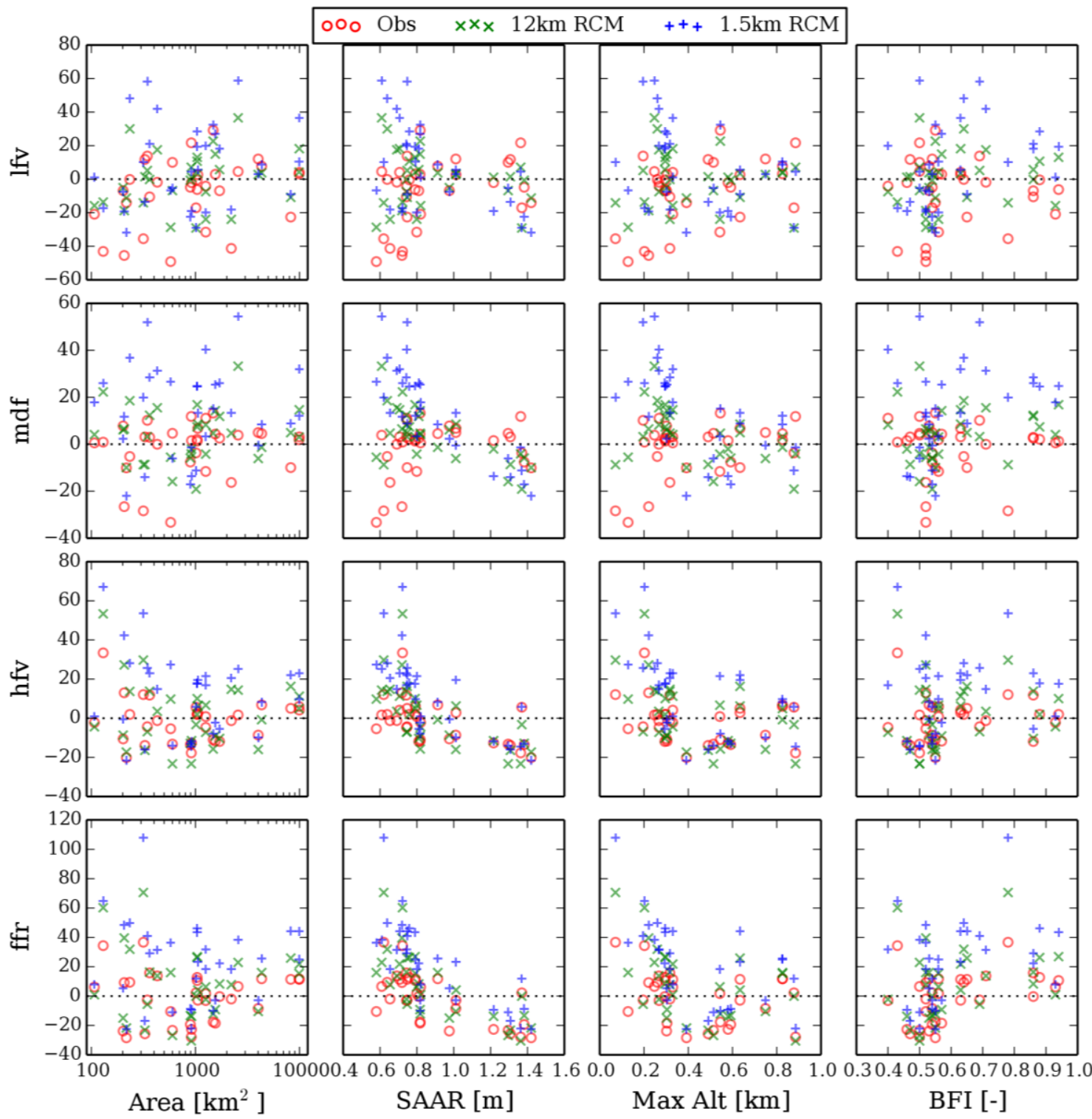

Figure 5 Plots of the four performance measures (Ifv, $m d f, h f v$, ffr), using observed inputs (red circles) and inputs from the 12km RCM (green crosses) and $1.5 \mathrm{~km}$ RCM (blue plus signs), against catchment area, standard annual average rainfall (SAAR), maximum catchment altitude (Max Alt) and baseflow index (BFI) (Table 2). 
$12 \mathrm{~km} \mathrm{RCM}$
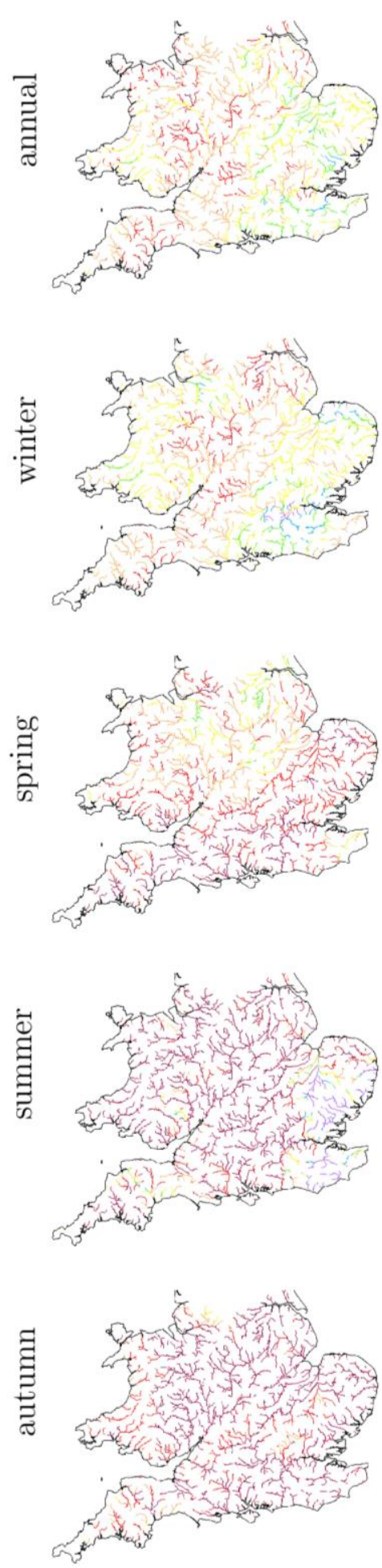

$1.5 \mathrm{~km} \mathrm{RCM}$
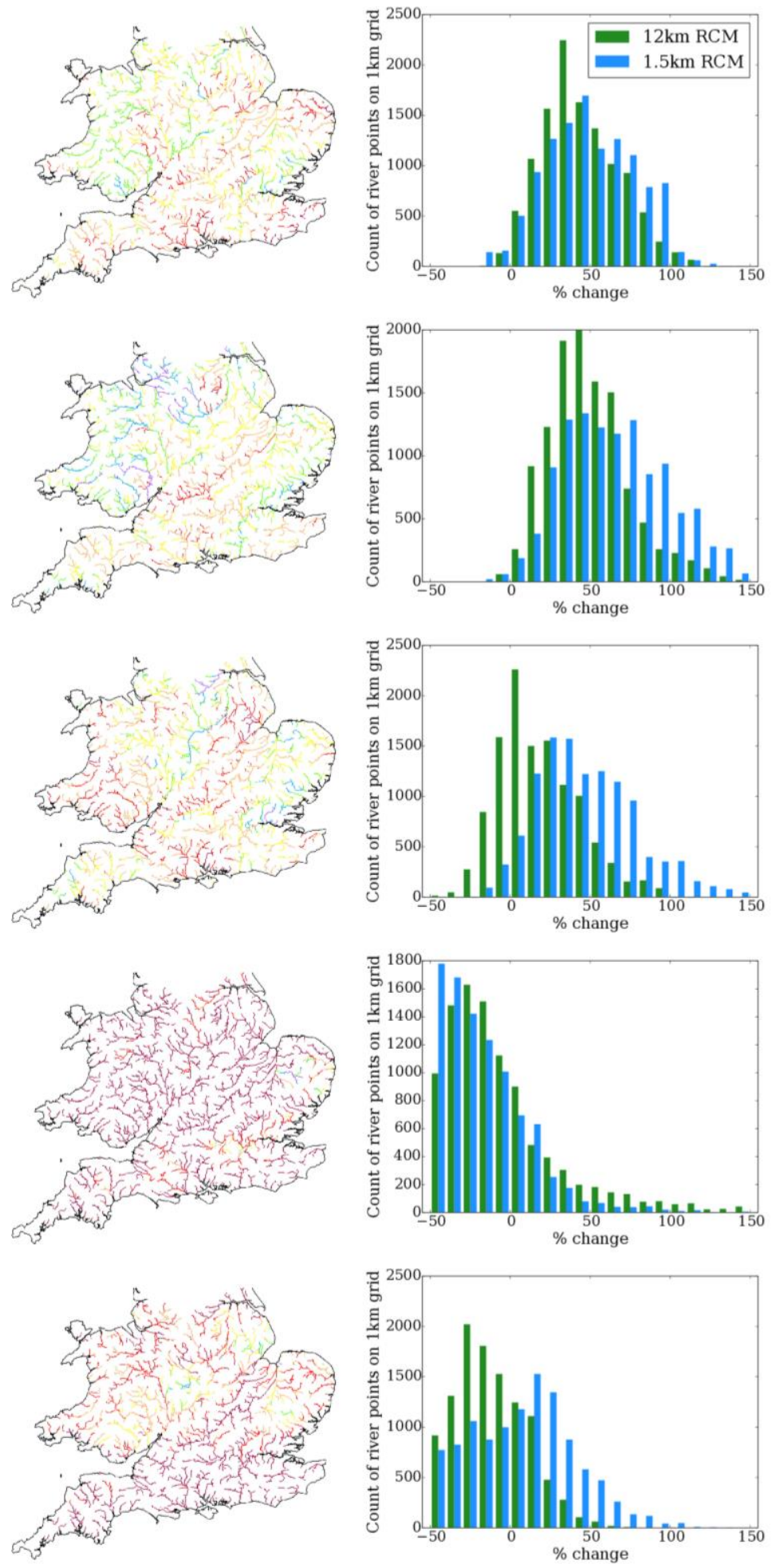

Figure 6 Maps of the percentage changes in annual and seasonal flood peaks with a 10-year return period, between the Current and Future timeslices, for the $12 \mathrm{~km} \mathrm{RCM} \mathrm{(left)} \mathrm{and} \mathrm{the} 1.5 \mathrm{~km}$ RCM (middle), together with histograms of the percentage changes shown in the maps (right). 